\title{
The Binding of Crystal Violet by Isolated Bacterial Cell-wall Material
}

\author{
By G. WISTREICH* AND J. W. BARTHOLOMEW \\ Microbiology Section, Department of Biological Sciences, \\ University of Southern California, Los Angeles, California 90007, U.S.A.
}

(Accepted for publication 27 August 1969)

SUMMARY

Isolated bacterial wall material from four Gram-positive and four Gramnegative organisms bound crystal violet as well as or better than intact bacteria. Dye binding ability varied between species. There was no correlation between the dye binding ability of isolated wall material and the Gram characteristics of the intact bacteria.

\section{INTRODUCTION}

Statements in the literature concerning the affinity of bacterial cell-wall material for basic dyes are indefinite. Knaysi (I95I) wrote '... the cell wall has a low affinity for dyes and is not usually coloured in common staining procedures... B. Bisset \& Hale (1953) reported 'In preparations stained by the routine bacteriological methods the external wall is unstained and invisible... . Lamanna \& Mallette (I954) reported that the walls of Gram-positive organisms were stainable with crystal violet but not with safranin, while those of Gram-negative organisms were not stainable with either dye. Hale \& Bisset (1956), in a study of several bacterial genera, observed that the walls of Gram-negative organisms were more difficult to stain than those of Gram-positives. All of the aforementioned studies concerning the staining ability of cell-wall material were performed using intact bacteria. As far as we are aware, only one report of dye uptake by partially isolated wall material exists, namely that of Scherrer (1963). Results of his investigations showed high dye uptake for a Mickle disrupted preparation of Bacillus megaterium which consisted of $95 \%$ disrupted and $5 \%$ intact organisms. No comparative dye uptake studies have appeared using isolated wall material. This paper is a report on such a study, using wall material from several species of Grampositive and Gram-negative organisms.

\section{METHODS}

Growth of organisms. Eight species of bacteria were employed, and all were obtained from the stock culture collection of the Microbiology Section, Department of Biological Sciences, University of Southern California. These included four Grampositive organisms, Bacillus subtilis, Clostridium sporogenes, Micrococcus roseus, and Sarcina lutea; and four Gram-negative organisms, Aerobacter aerogenes, Escherichia coli, Pseudomonas fluorescens, and Serratia marcescens. All, except Clostridium sporo-

* Present address: Department of Biological Sciences, East Los Angeles College, Los Angeles, California 90022, U.S.A. 
genes, were grown in Trypticase Soy Broth (Difco) in Erlenmeyer flasks in a reciprocating shaker water bath at $30^{\circ}$ for $24 \mathrm{hr}$. Clostridium sporogenes was grown in Thioglycollate Broth (Difco) in Erlenmeyer flasks in stationary culture at $30^{\circ}$. Bacillus subtilis was grown with butyric acid to prevent sporulation (Hardwick, Guirard \& Foster, 195I).

Cell-wall preparations. Intact bacteria were disrupted using the synthetic zeolite procedure described by Wistreich, Lechtman, Bartholomew \& Bils (I968). Following the disruption of bacteria, the wall fragments were isolated as follows, with all centrifugations conducted at $5^{\circ}$. The supernatant was saved following centrifugation at $2000 \mathrm{~g}$ for $10 \mathrm{~min}$., and subjected to $12,000 \mathrm{~g}$ for $30 \mathrm{~min}$. This pellet was washed in $\mathrm{M}-\mathrm{NaCl}$, and then in distilled water until the supernatant was free of $\mathrm{Cl}^{-}$. The pellet then was exposed to $100 \mu \mathrm{g}$. $/ \mathrm{ml}$. of crystalline trypsin at $\mathrm{pH} 7.6$ for $2 \mathrm{hr}$ followed by washing in distilled water until the wall material gave no absorption peak at $260 \mathrm{~m} \mu$ (Salton \& Horne, I95I $b$; Salton, I953). Suspensions of this material then were centrifuged at $3000 \mathrm{~g}$ for $10 \mathrm{~min}$. and the pellet discarded. The supernatant was then centrifuged at $12,000 \mathrm{~g}$ for $30 \mathrm{~min}$. The pellet obtained, on suspension in distilled water, was examined in the electron microscope and only those preparations were used which could be seen to consist entirely of cell-wall fragments (Salton \& Horne, I95 $b$; Salton, I953; Wistreich et al. 1968). The isolated wall preparations were then lyophilized and stored at $0^{\circ}$ until needed. Dry weights were determined by drying duplicate $2.0 \mathrm{ml}$. volumes of the wall suspensions at $105^{\circ}$ to constant weight. The procedures used were described in detail by Wistreich (I969).

Intact bacteria. Bacteria were killed by heating at $65^{\circ}$ for $30 \mathrm{~min}$., and then washed twice in sterile cold distilled water. The temperature of $65^{\circ}$ was chosen to avoid the disruptive effects of heat reported by Salton \& Horne (I95I $a, b$ ). Electron microscopy confirmed that the bacteria were not disrupted by this treatment. Dry weights were determined as for the wall preparations.

Determination of dye uptake. The colorimetric method described by Finkelstein \& Bartholomew (1953) was used except that the final speed of centrifugation needed to remove fragmented walls was $12,000 \mathrm{~g}$ for $30 \mathrm{~min}$., and all centrifugations were done at $5^{\circ}$. Valid comparisons of dye binding by different material requires that comparisons be made only when the material is saturated with dye (Bartholomew \& Finkelstein, 1954; Finkelstein \& Bartholomew, 1953). In the present experiments saturation was achieved by keeping the dye concentrations constant in a test series, and decreasing the concentration of the wall material. As the dye/wall material weight ratios increased, the amount of dye originally present eventually reached a point when it was in excess to that needed to achieve dye saturation of the wall material present. When the data obtained was plotted, using as the ordinate 'milligrams dye taken up per mg. of wall material', and using as the abscissa the 'dye/wall material ratio (by weight) present at the start', a curve was obtained which reached its maximum height at the point of dye saturation of the bacterial material (Finkelstein \& Bartholomew, 1953). The weight of dye bound per mg. of the dye saturated bacterial material could then be determined using the values indicated by the level portion of the curve.

Although Wistreich (I969) found very small residual quantities of zeolite in wall material prepared by the above method, he also reported that the zeolite present did not bind measurable amounts of crystal violet. The wall weight values reported here were corrected for the weight of any zeolite found to be present. This was done by 
solubilizing a known weight of the wall material preparation in conc. $\mathrm{HCl}$, at $95^{\circ}$, for $4 \mathrm{hr}$. The insoluble zeolite residue could then be centrifuged out and its weight subtracted from the original value.

\section{RESULTS}

Several points are demonstrated by the data presented in Table I. Isolated bacterial wall material bound crystal violet as well as or better than intact bacteria, and there was no correlation between its ability to bind dye and the Gram characteristic of analogous intact bacteria. The ability of bacterial wall material to bind crystal violet varied considerably between bacterial species.

Table I. Crystal violet bound by whole organisms and isolated wall material, when saturated by the dye

\begin{tabular}{clcc}
$\begin{array}{c}\text { Gram reaction of } \\
\text { intact organisms }\end{array}$ & \multicolumn{1}{c}{ Microorganism } & $\begin{array}{c}\text { mg. Crystal } \\
\text { violet/mg. } \\
\text { whole organisms }\end{array}$ & $\begin{array}{c}\text { mg. Crystal } \\
\text { violet/mg. } \\
\text { isolated wall } \\
\text { material }\end{array}$ \\
Gram-negative & $\begin{array}{l}\text { Escherichia coli } \\
\text { Pseudomonas fluorescens }\end{array}$ & 0.15 & 0.22 \\
& $\begin{array}{l}\text { Aerobacter aerogenes } \\
\text { Serratia marcescens }\end{array}$ & $($ a $)$ & 0.22 \\
& Clostridium sporogenes & $($ a) & 0.28 \\
& Micrococcus roseus & 0.19 & 0.44 \\
& Sarcina lutea & 0.30 & 0.20 \\
& Bacillus subtilis & 0.36 & 0.21 \\
& & & 0.28 \\
& &
\end{tabular}

(a) $=$ Determinations not made.

$(b)=$ Dye saturation was approached, but not achieved. Final dye uptake would be greater.

\section{DISCUSSION}

In view of the previous reports in the literature, the considerable affinity for basic dye of isolated bacterial wall material reported here was surprising. Especially pertinent would be the relationship of this dye affinity to the reported role of wall staining in the Gram differentiation of intact bacteria. Our data are in contradiction to the contention of Lamanna \& Mallette (1954) that Gram differentiation is the result of an affinity of crystal violet for the walls of Gram-positive organisms, and the lack of such affinity for walls of Gram-negative organisms. Certainly, the failure of dye uptake of wall material to correlate with the Gram characteristic of intact bacteria would indicate that dye affinity could not contribute in any essential manner to the process of Gram differentiation. Such a conclusion is supported by the finding of Bartholomew \& Finkelstein (1958) that the dye-iodine precipitate present interior to the cell wall, by itself, is sufficient to allow Gram differentiation.

The dye concentration used in a normal Gram staining procedure is Ioo-fold greater than that needed to saturate the cell material present, and such high dye concentrations are known to improve the differential results obtained (Bartholomew, 1962). On the addition of iodine, most of the dye-iodine precipitate formed would therefore come from the free dye present in the cell, rather than from the small amount of dye originally bound by cell material (Smyth \& Gershenfeld, 1960). Such 'charging' of the cell internal spaces with large amounts of the dye-iodine precipitate is the true function of 
the dye and iodine concentrations used in Gram stain procedures (Bartholomew, Cromwell \& Gan, I965). On the basis of the above, one could predict the failure of all attempts to correlate dye affinity for any cell material, with the true mechanism of Gram differentiation.

It should not be inferred, however, that the cell wall is unimportant in Gram differentiation. It has been demonstrated repeatedly that it has an extremely important role (Bartholomew \& Cromwell, 1965; Benians, I91 2; Burke \& Barnes, I929; Scherrer, 1963). For Gram-positive organisms it has been proposed that exposure to a decolorizer, such as $95 \%$ ethanol, causes a physico-chemical change in the wall material which retards passage of dye and iodine molecules through the wall; a change which does not occur with the wall material of Gram-negative organisms (Salton, 1963; Wensick \& Boevé, 1957). Also, Bartholomew et al. (1965) found that isolated cell-wall fragments could reflect the decolorization characteristics of analogous intact bacteria. These observations, along with the data presented in the present paper, strongly point to the physico-chemical nature of the wall material, and not to its dye binding ability, as the major contributing factor to the mechanism of Gram differentiation.

\section{REFERENCES}

BARTHOLOMEW, J. W. (1962). Variables influencing results, and the precise definition of steps in Gram staining as a means of standardizing the results obtained. Stain Technol. 37, I39.

Bartholomew, J. W. \& Cromwell, T. (1965). Relative contribution of the cell wall, cytoplasmic membrane, and cytoplasm to the Gram-positive characteristic of Bacillus megaterium. J. Bact. 9o, 643.

Bartholomew, J. W. \& Finkelstein, H. (1954). Crystal violet binding capacity and the Gram reaction of bacterial cells. J. Bact. 67,689 .

Bartholomew, J. W. \& Finkelstein, H. (1958). Relationship of cell wall staining to Gram differentiation. J. Bact. 75, 77.

Bartholomew, J. W., Cromwell, T. \& GAN, R. (1965). Analysis of the mechanism of Gram differentiation by use of a filter-paper chromatographic technique. J. Bact. 90, 766.

BenIANs, T. H. C. (19I2). Observations on the Gram-positive and acid-fast properties of bacteria. J. Path. Bact. 17, 199.

Bisset, K. A. \& Hale, C. H. F. (1953). Complex cellular structure in bacteria. Expl Cell Res. 5, 449.

BURKE, V. \& BARNES, M. W. (1929). The cell wall and the Gram reaction. J. Bact. 18, 69.

FinkelsteIN, H. \& BARTHOLOMEW, J. W. (1953). Quantitative determination of dye uptake by bacterial cells. Stain Technol. 28, 177.

HALE, C. M. F. \& Bisset, K. A. (1956). A comparison of the staining reaction of cell walls of Azotobacter chroococcum and those of Gram-positive and Gram-negative bacteria. J. gen. Microbiol. $15,423$.

HARDWICK, W. A., Gutrard, B. \& Foster, J. W. (I95I). Antisporulation factors in complex organic media. II. Saturated fatty acids as antisporulation factors. J. Bact. 6r, I45.

KNAYsI, G. (195I). Elements of Bacterial Cytology. 2nd ed., Ithaca, New York: Comstock Publishing Co. Inc.

LamanNa, C. \& Mallette, M. F. (1954). The cytological basis for the role of the primary dye in the Gram stain. J. Bact. 68, 509.

Salton, M. R. J. (1953). Cell structure and enzymic lysis of bacteria. J. gen. Microbiol. 9, 512.

SAlton, M. R. J. (1963). The relationship between the nature of the cell wall and the Gram stain. J. gen. Microbiol. 30, 223.

SAlton, M. R. J. \& HoRNE, R. W. (I95I $a$ ). Studies on the bacterial cell wall. I. Electron microspical observations on heated bacteria. Biochim. biophys. Acta 7, 19.

SAlton, M. R. J. \& HoRNE, R. W. (I95 I $b$ ). Studies on the bacterial cell wall. II. Methods of preparation and some properties of cell walls. Biochim. biophys. Acta 7, 177. 
SCHERRER, R. (1963). Cell structure and quantitative Gram stain of Bacillus megaterium. J. gen. Microbiol. 31, I35.

SMYTH, R. D. \& GeRSHENFELD, L. (1960). Iodine ${ }^{131}$ uptake in Gram staining technique. Stain Technol. 35, 237.

WeNSICK, F. \& BoevÉ, J. J. (I957). Quantitative analysis of the Gram reaction. J. gen. Microbiol. 17, 401.

Wistreich, G. A. (1969). Studies of bacterial cell wall preparation and dye uptake. Ph.D. thesis, University of Southern California, Los Angeles, California.

Wistreich, G. A., Lechtman, M. D., Bartholomew, J. W. \& Bils, R. (I968). Disruption of bacterial cells by a synthetic zeolite. Appl. Microbiol. 16, 1269. 